\title{
Development of microengineered systems to initiate, analyze and control stem cell patterning
}

Citation for published version (APA):

Samal, P. (2021). Development of microengineered systems to initiate, analyze and control stem cell patterning. [Doctoral Thesis, Maastricht University]. Maastricht University. https://doi.org/10.26481/dis.20210903ps

Document status and date:

Published: 01/01/2021

DOI:

10.26481/dis.20210903ps

Document Version:

Publisher's PDF, also known as Version of record

\section{Please check the document version of this publication:}

- A submitted manuscript is the version of the article upon submission and before peer-review. There can be important differences between the submitted version and the official published version of record.

People interested in the research are advised to contact the author for the final version of the publication, or visit the DOI to the publisher's website.

- The final author version and the galley proof are versions of the publication after peer review.

- The final published version features the final layout of the paper including the volume, issue and page numbers.

Link to publication

\footnotetext{
General rights rights.

- You may freely distribute the URL identifying the publication in the public portal. please follow below link for the End User Agreement:

www.umlib.nl/taverne-license

Take down policy

If you believe that this document breaches copyright please contact us at:

repository@maastrichtuniversity.nl

providing details and we will investigate your claim.
}

Copyright and moral rights for the publications made accessible in the public portal are retained by the authors and/or other copyright owners and it is a condition of accessing publications that users recognise and abide by the legal requirements associated with these

- Users may download and print one copy of any publication from the public portal for the purpose of private study or research.

- You may not further distribute the material or use it for any profit-making activity or commercial gain

If the publication is distributed under the terms of Article $25 \mathrm{fa}$ of the Dutch Copyright Act, indicated by the "Taverne" license above, 


\section{Summary}

This thesis is a combination of five main chapters which follow a common theme of analyzing and controlling cell patterning using microengineered platforms, while trying to make these techniques more accessible to the biological community.

In Chapter 1, which also serves an introduction, how microengineering and microfluidics can help improve in vitro morphogenetic models is highlighted. This introduction summarizes the current state-of-the-art of recently developed in vitro morphogenetic models and discusses the current and future roles that microfluidic systems play in these advancements. These models are an attractive alternative to in vivo embryonic studies, which lack accessibility and are fraught with ethical issues. However, customized cell culture platforms are needed to unleash their full potential.

In Chapter 2, a new, microengineered platform for 3D suspension culture of mouse stem cell aggregates is presented; enabling microscale control of the position and orientation of elongating stem cell aggregates and real-time data acquisition at single cell resolution.

In Chapter 3, a microengineered fluorinated ethylene-propylene (FEP)-based cell culture platform is presented which shows excellent optical properties. The microcavities can be utilized in conjunction with brightfield and fluorescence microscopy and support machine learning-based label-free feature extraction. The system's potential for drug and small molecule testing is showcased using 3D mouse embryonic stem cell (mESC) aggregates, which mimic certain aspects of embryonic development.

In Chapter 4, a direct photolithography method has been described which enables fabrication of microstructures in bulk poly(methyl methacrylate) (PMMA). The method has been used to create artificial signaling centers on microfluidic chips to control mouse embryonic stem cell patterning. This work opens new avenues for microfabrication of microfluidic and optofluidic systems in the biomedical field.

In Chapter 5, a direct deep ultraviolet (DUV) photolithography method, which enables fabrication of microstructures in bulk polystyrene cell culture substrates has been described. Pipelines for generating ink based DUV masks and micropattern virtualization further increase the remarkable straightforwardness of the process. This, combined with the high applicability can significantly improve accessibility of this class of microfabrication techniques to a new and broad biological research community. 